Edubiotik: Jurnal Pendidikan, Biologi dan Terapan

ISSN 2528-679X (print), ISSN 2597-9833 (online)

Vol. 6, No. 01, February 2021, pp. $74-82$

Available online at:

http:/lejurnal.budiutomomalang.ac.id/index.php/edubiotik

Research Article

\title{
Phylogenetic analysis of the grouper family (Serranidae) from various local markets in Indonesian waters using $\mathrm{COI}$ (cytochrome oxidase I)
}

\author{
Tomi Apra Santosa*, Winda Ayu Fietri, Abdul Razak, Ramadhan Sumarmin \\ Biology Study Program, Universitas Negeri Padang, Padang, Indonesia \\ Email: santosatomiapra@gmail.com*, windaayufietri90@gmail.com, abdulrazakunp@gmail.com, \\ Ramadan_unp@gmail.com
}

\begin{tabular}{|c|c|}
\hline Article Information & ABSTRACT \\
\hline $\begin{array}{l}\text { Submitted: } 2020-12-12 \\
\text { Accepted: } 2021-05-24 \\
\text { Published: } 2021-05-24\end{array}$ & $\begin{array}{l}\text { Grouper fish (Serranidae) is a type of fish found in Indonesian waters. However, } \\
\text { not many people have conducted further research on phylogenetics based on COI } \\
\text { (Cytochrome Oxidase I). This study aims to explain the phylogeny of grouper fish } \\
\text { from the Serranidae family based on COI (Cytochrome Oxidase I). This research } \\
\text { is a literature study. The research samples were grouper fish from Lombok, } \\
\text { Karimunjawa, Lampung, Kendari, Madura, Tanakeke, and Numfor. The research } \\
\text { instrument was a grouper-type observation sheet and an observation sheet for the } \\
\text { results of the MEGA } 7 \text { application test. The data were analyzed using qualitative } \\
\text { descriptive analysis. The results showed that the level of kinship between the } \\
\text { species tested was very close, including Epinephelus areolatus, E. merra, E. } \\
\text { fasciatus, E. longispinis, E. coioides, E. ongus, and E. coeruleopunctatus with all } \\
\text { genetic distance averages type. O.02. The conclusion of this study is that in } \\
\text { general the species relationships found are several species found in the same } \\
\text { location with similar morphology and diet. }\end{array}$ \\
\hline & Keywords: Phylogenetic; Serranidae; grouper fish; cytochrome oxidase I \\
\hline Publisher & How to Cite \\
\hline $\begin{array}{l}\text { Biology Education Department } \\
\text { IKIP Budi Utomo, Malang, Indonesia }\end{array}$ & $\begin{array}{l}\text { Santosa, T., Fietri, W. A., Razak, A., \& Sumarmin, R. (2021). Phylogenetic } \\
\text { analysis of the grouper family (Serranidae) from various local markets in } \\
\text { Indonesian waters using COI (cytochrome oxidase I). Edubiotik: Jurnal } \\
\text { Pendidikan, Biologi dan Terapan, 6(01) 74-82. https://doi.org/10.33503/ebio.v6i01. } \\
1204\end{array}$ \\
\hline 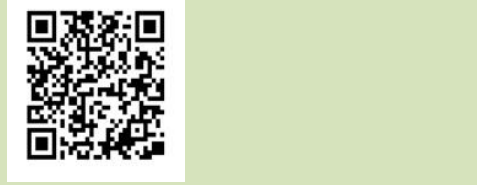 & $\begin{array}{l}\text { Copyright } \odot 2021 \text {, Santosa et al. } \\
\text { This is an open access article under the CC-BY-SA license } \\
\text { (c) (i) (-) }\end{array}$ \\
\hline
\end{tabular}

\section{INTRODUCTION}

Fish found in Indonesia is the grouper fish which is one of them an economical fish consumed by the public. Grouper fish are widely known in coastal waters tropical and subtropical, and globally a very important group of marine fish commercial, which has a high value market and is the main target of fisheries. Grouper (Epinephelus sp.) is included in thefamily, Serranidae classified as demersal and coral fish There are 159 species of species in the world and 39 species can be found in Indonesia, while 46 types can be found in Southeast Asia (Aznardi \& Madduppa, 2020). Grouper fish belong to the 
family Serranidaewhich have a tendency to live solitary and the type of fish is protogini hermaphrodite (Mujiyanto et al., 2015). Grouper fish, this type of demersal fish resides in water, such as in crevices or in caves bottom waters. Grouper fish are widely known in tropical and subtropical environments in general on the market representatives of three genera namely Epinephelus, Cromileptes and Plectropomus (Aqil et al., 2019).

Grouper fish are a group of fish that have an important role both ecologically and the economy. Ecologically, in the coral reef ecosystem the grouper is a living predator in special habitats. Economically, grouper has a high economic value, apart from that Indonesia's leading non-oil and gas export commodities are $9.38 \%$ of Hong Kong's needs so that its sustainability is closely related to fishermen's source of income (Sulistyowati et al., 2018). Grouper exploitation activities by aquatic communities such as Peukan Bada has been going on for a long time. Currently the fishermen began to feel the symptoms of overexploitation/overfishing (Astuti, 2018). More intensive grouper fishing without regard can decent size increased threats to catch fish Group Serranidae husband (Ramadhani et al., 2017).

The potential for grouper fish in Indonesia has decreased due to pressure arrest. The market demand continues to increase and its economic value height has increased the increase in energy increase, so that grouper fish resources are vulnerable against the threat of extinction. Apart from this, the activity of catchers using tools arrests that are not environmentally friendly still occur, such as the use of anesthesia, bombs and use breathing apparatus (compressor). The use of fishing gear can damage the ecosystem growing corals which are fish habitats (Setiawan et al., 2019).

Based on the results of research by Jefri, et.al (2015) through DNA amplification using mitochondrial cytochrome oxidase I produced a long sequence of 526 base pairs in all samples. A total of seven species of grouper fish were characterized, namely; Epinephelus areolatus, E. merra, $E$. fasciatus, E. longispinis, E. coioides, E. ongus, and E. Coeruleopunctatus (Jefri et al., 2015). All was found to belong to 7 distinct clades in the constructed phylogenetic tree. E. ongus in genetic distance is closest to $E$. coeruleopunctatus with a genetic distance of $0.091(9 \%)$, while distance geneticidentified between $\mathrm{E}$. ongus and $\mathrm{E}$. Merra 0.178 distancewith genetic distance $(18 \%)$.

Research by Kamal, et.al (2019) of $30 \mathrm{mg}$ of fin meat from each fish was taken for isolation and DNA extraction, then visualization of COI gene electrophoresis and DNA fragmentation using the PCR sequencing method. After extraction, 20 well-visualized DNA samples were obtained, of which 16 samples could be amplified. The results show that there are 6 authenticated species. The first group was Variola albimarginata, Cephalopholis urodeta, and C. sexmaculata with a similarity level of $\geq 97 \%$. Next, C. boenak, Epinephelus merra, and Scolopsis vosmeri, thelevel was similarity $\leq 97 \%$. When compared to the results of DNA authentication, the results showed that 13 samples or $80 \%$ were not correctly identified morphologically. Based on genetic distance, the phylogeny tree forms 2 clades between Serranidae and Nemipteridae. The results show that the use of COI gene markers is very effective for species authentication which can be used as an instrument in grouper management and management (Kamal et al., 2019). This study aims to analyze the phylogenetics of grouper fish (Serranidae) from various local markets in Indonesian waters using the COI (Cytochrome Oxidase Imarking).

\section{RESEARCH METHODS}

Singer research is a literature study (library research).Literature study is a type of research that seeks and examines various sources of literature that come from various relevant sources (Santosa et 
al., 2021). This research was conducted in January - May 2020. Samples came from 39 groupers collected from local fishermen in Lombok (12 samples) in January, Karimunjawa (11 samples) in May, Lampung (4 samples) in February, Kendari (3 samples) in January, Madura (3 samples) in April, Tanakeke ( 3 samples) in February, and Numfor ( 3 samples) in May. The species to be tested were Epinephelus areolatus, Epinephelus merra, Epinephelus fasciatus, Epinephelus longispinis, Epinephelus coioides, Epinephelus ongus, and Epinephelus coeruleopunctat. In addition, research data also comes from reputable national and international journal articles accessed through google scholar, science direct, emerald journal, PubMed, sage journal, and NCBI related to fish. The data analysis technique in this study used the MEGA 7 application.

\section{FINDINGS AND DISCUSSION}

Thesubfamily Epinephelinae is a group of carnivorous marine fish belonging to the family Serranidae. Most of the grouper species are coral reef, but a few inhabit estuaries or on coral reefs. Grouper fish have potential economic value in the field fishery. However, classification and evolutionary relationships often arise by the number of species that are present remarkable, wide distribution, and lack of morphological keys used in the classification (Ariyanti \& Farajallah, 2019). Grouper fish (grouper) generally live in reef ecosystems coral which has important ecological value because it is the main predator in the food chain. Apart from its ecological value, grouper fish also has important economic values, including being a commodity reef fisheries are mostly exploited in both domestic and international markets (Astuti, 2018).

Phylogeny aims to represent the evolutionary history of organisms by defining natural groups (monophyletic). Phylogenetic classification is the best way to do this compile information on biodiversity and it has become a universal practice in classification biology. Understanding not only diversity but also diversity phylogenetics gives us a comparative view of the evolution and distribution between the lines heredity, be it morphological, biological, or molecular. All kinds agreed between living things according to their phylogenetic origin, and thus serve as sources of information for the discovery of phylogenetic history (Malabarba \& Malabarba, 2020).

Knowledge of kinship is a need to learn evolution of related taxa by comparing their DNA. Science phylogenetics can predict evolution that occurred in the past by comparing sequences DNA or Protein. Phylogenetics can show the evolutionary relationship of an organism from morphological and molecular data (Akbar et al., 2018). Species identification using mitochondrial DNA has the advantage of its size smaller, large number of regions, complete DNA sequence information available for aquatic organisms, and no non-coding ranges. DNA barcoding is a method that is often used in taxonomic forensics because it is effective in identifying a variety of sample conditions and not produce ambiguous data (Maulid et al., 2016).

The use of morphometric data is important to determine whether fish are being caught is feasible to take, while the use of DNA barcoding is done to verify whether there is an error or not in determining the taxonomy of the fish studied, because so far some fish species experience ambiguity in taxonomy. Molecular genetics needs to be linked with identified precision and supports the results based ontraits morphological. Accurate identification of an organism from genus to subspecies level. Morphology is difficult to distinguish and creates ambiguity, so DNA barcoding can be used. Ambiguity and errors in data errors can be a threat to activities sustainable fisheries conservation. Several studies have been able to identify fish. Rahim \& Madduppa (2020), explains commercials from Indonesian waters use 
molecular genetic techniques, including snapper (Lutjanus), grouper (Epinephelus), mackerel (Scomberomorus), and tuna (Thunnus).

Molecular identification through DNA barcode media has its advantages species verification and has been proven successfully in various marine organisms such as stingrays. System system based on DNA Barcoding is applicable for all types of animals in advance to find out fish. This method was first developed by Herbert et al. by using the COI gene marker located in the mitochondria so that they are able to vary the nucleotide bases in each species (Aznardi \& Madduppa, 2020). The CO 1 gene has many advantages for knowing genetic information because there are very few deletions and insertions in the sequence, and many parts are of a character. Conservation this can be used as barcoding DNA in most species. CO 1 gene can also be used to reconstruct phylogenetics at the evolutionary branch of the species level. Other than that the amino acid sequence of the protein encoded by the CO 1 gene rarely undergoes substitution so that the $\mathrm{CO}$ gene 1 is stable and can be used as a marker for phylogeny analysis, but bases in triple. The codon is still changing and is silent, which is a base change that does not change the type of acid amino (Wirdateti et al., 2016).

Mitochondria in particular mitochondrial DNA (mtDNA) is a DNA strands are passed down by the female parent and mtDNA is good for analysis distribution or descent of a species. Observation of mtDNA is reported to be supportive various studies to get good information in studying the genetic structure, at among fish populations (Hariyanto et al., 2015). Mitochondria Cytochrome c Oxidase subunit I (COI) is mitochondrial DNA genes that code for proteins, which aid in cellular respiration. The 650-pair area of the mitochondrial COI base serves as a common barcode for animals due to its relatively fast mutation rate in a relatively short time, high exon number, and maternal inheritance (Imtiaz et al., 2017). The analysis carried out departed from the initial research conducted by Jefri et al (2015), who conducted a BLAST analysis on Serranidae obtained from the NCBI (National Center For Biotechnology Information) Gen Bank. The phylogeny was made using the Neighbor Joining (NJ) phylogenetic analysis and the Maximum Likelihood (ML) method with the 2-parameter Kimura. From the results of the study, seven species were found, namely from the genus Epinephelus which was indicated by a similarity value of $99 \%$ - 100\% (Jefri et al., 2015).

In addition, research conducted by Kamal et al (2019) showed that there were 6 authenticated species. The first group was Variola albimarginata, Cephalopholis urodeta, and C. sexmaculata with a similarity level of $\geq 97 \%$. Next, C. boenak, Epinephelus merra, and Scolopsis vosmeri, the similarity level was $\leq 97 \%$. When compared to the results of DNA authentication, the results showed that 13 samples or $80 \%$ were not correctly identified morphologically. Based on genetic distance, the phylogeny tree forms 2 clades between Serranidae and Nemipteridae. The results show that the use of $\mathrm{COl}$ gene markers is very effective for species authentication which can be used as an instrument in grouper management and management.

In this study, the grouper sequences found included all of the genus Epinephelus. Gene sequences analyzed using the MEGA X program, the sequence sequences were obtained from NCBI (National Center for Biotechnology Information) Gen Bank. The selected COI sequence sequence is then stored in FASTA format and some sequence alignment is done in the MEGA X program. Phylogeny tree made using phylogenetic analysis of Neighbor Joining (NJ) and the Maximum method Likelihood (ML) with 2-parameter Kimura. Nucleotide sequences were analyzed alignment sequences (edit / alignment build) with Clustal-W with MEGA X software. Multiple sequences likeness is cut at the 5 'end, 3 ' end or remainder. Phylogenetic analysis using methods Maximum likelihood with bootstrap is 1000 using the 2-parameter Kimura model. Phylogenetic trees that have been formed into 2 types, 
namely the original and the bootstrap result (Anafarida, 2020). The author has conducted an analysis using MEGA $X$ and software obtain phylogenetic tree data and analysis of genetic distances between species found. Tree phylogenetics are presented in Figure 1.

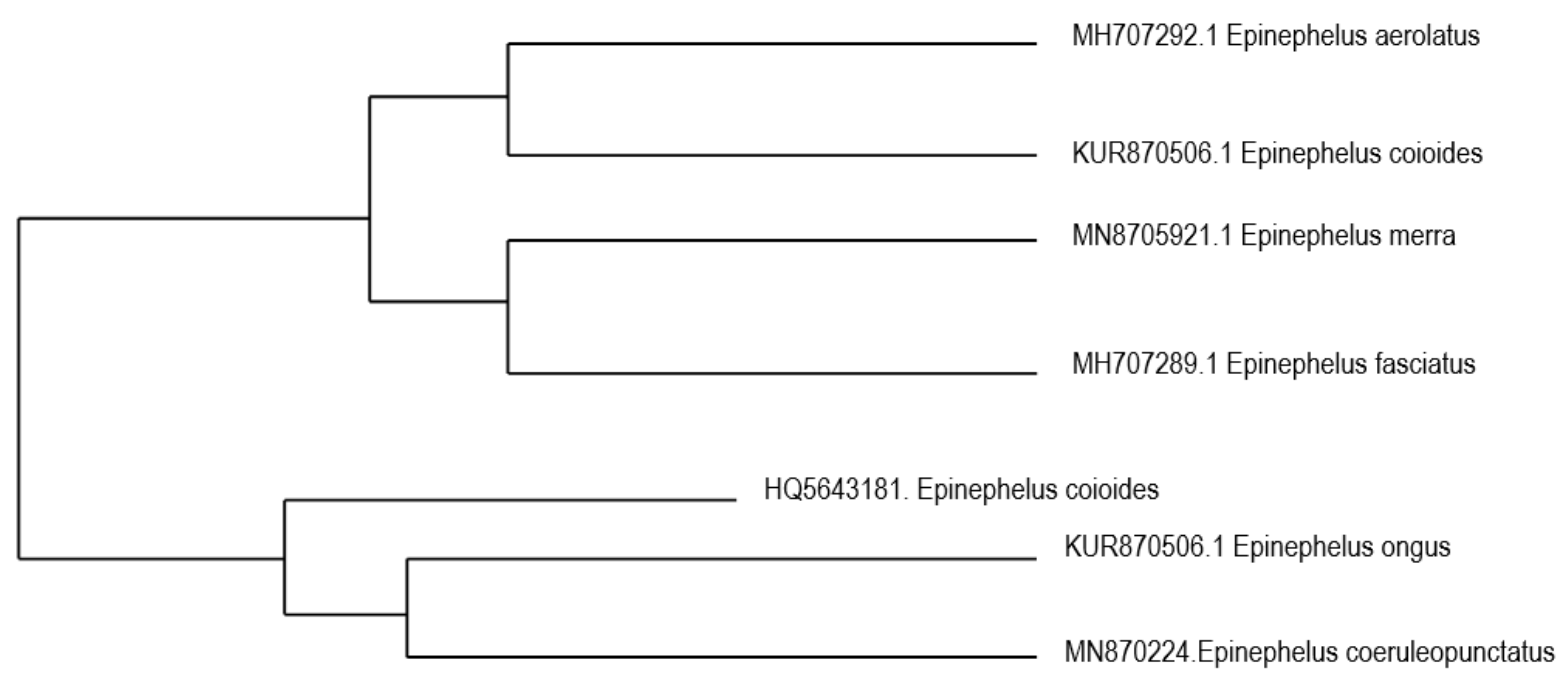

Figure 1. Grouper Phylogenetics Serranidae in Indonesia Collected from Local Fish Markets

The results of phylogenetic analysis show that the species Epinephelus areolatus are very close to Epinephelus longispinis (82\%), Epinephelus merra and Epinephelus longispinis are also closer. For Epinephelus fasciatus it is very close to Epinephelus merra (91\%), Epinephelus coioides and Epinephelus fasciatus are also closer. For Epinephelus coioides, Epinephelus ongus and Epinephelus coeruleopunctatus are closely related, namely (99\%), Epinephelus ongus and Epinephelus coeruleopunctatus are also closely related $(70 \%)$ and slightly further from Epinephelus areolatus. However, based on these data, it is estimated that each Epinephelus has a close relationship with othergroups Epinephelus . In the phylogenetic tree, these reef fish species form closely related groups, supported by high bootstrap values $(99 \%, 91 \%, 82 \%$ and $70 \%)$ and an average genetic distance of 0.02 .

Seven clades form a grouping and represent a dense tree, each clade showing a bootstrap value of $99 \%, 91 \%, 82 \%$ and $70 \%$. Morphologically, Epinephelus spp. difficult to distinguish because the characteristics are very similar, but this can be traced by the results of molecular analysis. Mitochondria COI genes, as an ideal area for species barcodes, DNA barcodes can be used for rapid analysis for confirmation for specific species. This study becomes important data for sustainable conservation management and trade in grouper (Epinephelus spp.) in Indonesia. (Jefri et al., 2015). In addition to similar morphology, habitat is also one of the causes of phylogeny tree linkages, grouper habitat is found at a depth of \pm 10 -11 meters of grouper fish more than the base of hard corals dominated by massive corals that form gaps or holes at the base of coral colonies. Grouper fish behavior has a regional tendency with low readiness (a bit dark) with its movement tending to move to deeper waters (Mujiyanto et al., 2015).

The grouper Epinephelus areolatus is grouperfamous protogini wide West Indian Ocean, East Indian Ocean, and Western Central Pacific. Compared another grouper species, E. areolatus is characterized by (1) its dependence on vegetation habitat, viz algae and seagrass beds, and (2) are relatively small in size with a maximum total observed length of $470 \mathrm{~mm}$. In the western part of the Bay 
E. areolatus is usually harvested, along with other grouper species, using nets, gill nets, long lines, and fishing line (Lin et al., 2019).

The species $\mathrm{E}$. fasciatus can tolerate temperatures in the range $23-27 \mathrm{oC}$. This fish is associated with coral, can live at a depth of 20-45 meters. E. fasciatus which is adaptable to conditions the environment of the lagoon waters to coral reef areas (Astuti et al., 2016). E. coioides, large and medium sized warmwater marine fish which are well known in tropical and subtropical waters, is an economically important and widely cultivated fish in South China (Huang et al., 2020). Fish the mud grouper (Epinephelus coioides) has a large head, wide mouth, and body small scales. The edge of the operculum, serrated and there are spines on the operculum. The location of the two fins apart (the first in the form of thorns), apart. All types of grouper have three spines on the anal fin and three spines on the edge of the operculum.

White spotted grouper Epinephelus coeruleopunctatus in the waters of Padang City (Ramadhani et al., 2017). The white spotted grouper Epinephelus coeruleopunctatus is one of the fish commercial area in the waters of the city of Padang. Unfortunately like other grouper species, this species also rare and difficult to catch (Bulanin et al., 2017). Maximum likelihood analysis method using the Kimura-2 model to reconstruct the relationships between species based on line lengths branch. The different long lines indicate the evolutionary rate of each species. That line the longer it shows the further evolutionary distance, while the shorter the line show evidence of the evolution of a species (Anafarida, 2020). The results of other studies also showed that each species of the genus Epinephelus showed similarity of $99 \%-100 \%$. The genetic distance data of the seven species ranged from $0.091(9 \%)$ to $0.178(18 \%)$. The closer the genetic distance of one species to another, namely the COI gene which has a closer similarity and the value of the genetic distance is still in the middle boundary (Jefri et al., 2015). Phylogenetic analysis of grouper fish (Serranidae) in Indonesian local markets can be seen in Figure 2.

\begin{tabular}{|l|l|l|l|l|l|l|l|}
\hline No & & & & & & & \\
\hline 1 & MH707292.1 Epinephelus aerolatus & & & & & & \\
\hline 2 & MN8705921.1 Epinephelus merra & 0.1650 & & & & & \\
\hline 3 & MH707289.1 Epinephelus fasciatus & 0.1623 & 0.1281 & & & & \\
\hline 4 & HQ5643181. Epinephelus coioides & 0.1352 & 0.1663 & 0.1651 & & & \\
\hline 5 & KUR870506.1 Epinephelus coioides & 0.1842 & 0.1833 & 0.1779 & 0.1653 & & \\
\hline 6 & KUR870506.1 Epinephelus coioides & 0.1868 & 0.1758 & 0.1660 & 0.1794 & 0.1202 & \\
\hline 7 & $\begin{array}{l}\text { MN870224. Epinephelus } \\
\text { coeruleopunctatus }\end{array}$ & 0.1827 & 0.1563 & 0.1671 & 0.1357 & 0.1357 & 0.0962 \\
\hline
\end{tabular}

Figure 2. Phylogenetic Analysis of Grouper Fish (Serranidae) in Indonesian Local Markets

The results of genetic jatropha analysis show that the closest jatropha is between Epinephelus coeruleopunctatus and Epinephelus ongus (9.62\%). Meanwhile, the farthest distance is between Epinephelus ongus and Epinephelus areolatus (18.68\%). From the observations, the genetic distance between Epinephelus areolatus with Epinephelus othervaries and the tara is against Epinephelus merra (16.5\%), Epinephelus fasciatus (16.23\%), Epinephelus Iongispinis (13.52\%), Epinephelus coioides (18.42\%), and Epinephelus coeruleopunctatus (18.27\%). The genetic distance between Epinephelus merra and Epinephelus otheralso varies, among others, against Epinephelus fasciatus (12.81\%), 
Epinephelus longispinis (16.63\%), Epinephelus coioides 18.33 (\%), Epinephelus ongus (17.58\%), and Epinephelus coeruleopunctatus (15.63\%).

The genetic distance between Epinephelus fasciatus and Epinephelus otheralso varies against Epinephelus longispinis (16.51\%), Epinephelus coioides (17.79\%), Epinephelus ongus (16.6\%), and Epinephelus coeruleopunctatus (16.71\%). The genetic distance between Epinephelus longispinis and Epinephelus is othernot too varied, including Epinephelus coioides (16.53\%), Epinephelus ongus (17.94\%), and Epinephelus coeruleopunctatus (14.42\%). The genetic distance between Epinephelus coioides and Epinephelus is otheronly for two species, namely Epinephelus ongus (12.02\%) and Epinephelus coeruleopunctatus (13.57\%). Distances are calculated using the Kimura-2-parameter method integrated in MEGA X. Genetic distance analysis is an analysis based on matrix calculations of the "distance" between base pairs between sequences that link evolutionary distances (Monalisa et al., 2019). Similar research also states that the distance between sequences or genetic distance between groupers shows that the lowest inheritance of $0.002(0.2 \%)$ is seen between the sample codes. Based on the construction of the phylogeny tree, all individuals who have close kinship are on connected twig nodes, and each genus forms a cluster (clade) as seen in the genera Cephalopholis, Variola, Epinephelus, and Scolopsis (Kamal et al., 2019).

\section{CONCLUSION}

The conclusion of this study is that the level of kinship between the tested species is very close, including Epinephelus areolatus, E. merra, E. fasciatus, E. longispinis, E. coioides, E. ongus, and $E$. coeruleopunctatus. The average genetic distance of all species is 0.02 . In general, the related species found are several species found in the same location with almost the same morphology and diet.

\section{ACKNOWLEDMENT}

The research team would like to thank Dr. Abdul Razak, M.Si as the Head of the Department of Biology Education at the State University of Padang, who has provided guidance and assistance for both material and non-material research and to Mr. Dr. Ramadan Sumarmin ,. M.Si who has guided and fostered researchers in completing this research.

\section{REFERENCES}

Akbar, N., Aris, M., Irfan, M., Tahir, I., \& Baksir, A. (2018). Kajian filogenetik ikan tuna (Thunnus spp.) sebagai data pengelolaan di perairan sekitar Kepulauan Maluku, Indonesia. Jurnal Kelautan, 11(2), 120-129. https://doi.org/10.21107/jk.v11i2.3459

Anafarida, O., \& Badruzsaufari. (2020). Analisis filogenetik mangga (Mangifera spp.) berdasarkan gen 5,8S rRNA. ZIRAA'AH: Majalah IImiah Pertanian, 45(2016), 120-126. Retrieved from https://ojs.uniska-bjm.ac.id/index.php/ziraah/article/view/3001

Aqil, M., Indriyani, N., Abidin, L. O. B., \& Megawati. (2019). Deteksi Megalocytivirus pada ikan kerapu budidaya di Sulawesi Tenggara menggunakan metode polymerase chain reaction berdasarkan gen major capsid protein. Media Akuatika: Jurnal IImiah Jurusan Budidaya Perairan, 4(2), 61-67. Retrieved from http://ojs.uho.ac.id/index.php/JMA/article/view/7850

Ariyanti, Y., \& Farajallah, A. (2019). Short communication: Species confirmation of juvenile cloudy grouper, Epinephelus erythrurus (Valenciennes, 1828), based on a morphologic analysis and partial CO1 gene sequencing. BIODIVERSITAS, 20(3), 914-921. https://doi.org/10.13057/biodiv/ d200341

Astuti, Rika, Yonvitner, \& Kamal, M.M. (2016). Community structure of grouper fish (Serranidae) landed in Peukan Bada Subdistrict, Aceh Province. Jurnal IImu dan Teknologi Kelautan Tropis, 8(1), 73- 
84. Retrieved from https://journal.ipb.ac.id/index.php/jurnalikt/article/view/12497

Astuti, R. (2018). Kajian stok ikan kerapu (Cephalopolis sonnerati) berbasis hubungan panjang-berat yang didaratkan di tempat pendaratan ikan Ihok peukan bada, Kabupaten Aceh Besar, Provinsi Aceh. Retrieved from https://www.semanticscholar.org/

Aznardi, S., \& Madduppa, H. (2020). Identification of grouper (Epinephelus sp.) at Muara Angke traditional fish market in North Jakarta using morphology and DNA barcoding methods. Berkala Perikanan Terubuk, 48(1), 298-303. Retrieved from https://terubuk.ejournal.unri.ac.id/index.php/ JT/article/view/7905

Bulanin, U., Masrizal., \& Muchlisin, Z. A. (2017). Length-weight relationships and condition factors of the whitespotted grouper Epinephelus coeruleopunctatus bloch, 1790 in the coastal waters of Padang City, Indonesia. Aceh Journal of Animal Science, 2(1), 23-27. https://doi.org/10.13170/ ajas.2.1.6570

Huang, L., Qi, W., Zuo, Y., Alias, S.A., \& Xu, W. (2020). The Immune response of a warm water fish orange-spotted grouper (Epinephelus coioides) Infected with a typical cold water bacterial pathogen Aeromonas Salmonicida is AhR dependent. Developmental and Comparative Immunology, 113(July), 103779. https://doi.org/10.1016/j.dci.2020.103779

Imtiaz, A., Nor, S. A. M., \& Naim, D. M D. (2017). Progress and potential of DNA barcoding for species identification of fish species. Biodiversitas Journal of Biological Diversity, 18(4), 1394-1405. https://doi.org/10.13057/biodiv/d180415

Jefri, E., Zamani, N. P., Subhan, B., \& Madduppa, H.H. (2015). Molecular phylogeny inferred from the mitochondrial DNA of grouper Epinephelus spp. in Indonesia it is collected from local fish markets. Biodiversitas Journal of Biological Diversity, 16(2), 254-263. https://doi.org/10.13057/ biodiv/d160221

Kamal, M. M., Hakim, A. A., Butet, N. A., Fitrianingsih, Y., \& Astuti, R. (2019). Autentikasi spesies ikan kerapu berdasarkan marka gen MT-COI dari perairan Peukan Bada, Aceh. Jurnal Biologi Tropis, 19(2), 116 - 123. https://doi.org/10.29303/jbt.v19i2.1245

Lin, Y.J., Roa-Ureta, R. H., Rabaoui, L., Grandcourt, E. M., Maneja, R. H., Al-Abdulkader, K., \& Qurban, M. A. (2019). Association to vegetated habitats and different vulnerability to habitat degradation for two fish species, Epinephelus areolatus (Serranidae) and Siganus canaliculatus (Siganidae), from the western Arabian Gulf. Marine Pollution Bulletin, 141(April), 482-492. https://doi.org/10.1016/j.marpolbul.2019.03.011

Malabarba, L.R., \& Malabarba, M.C. (2020). Phylogeny and classification of neotropic fish. ACADEMIC PRESS, 1-19. https://doi.org/10.1016/B978-0-12-815872-2.00001-4

Maulid, D. Y., Nurilmala, M., Nurjanah, N., \& Maduppa, H. (2016). Molecular characteristics of cytochrome B for mackerel barcodes. Jurnal Pengolahan Hasil Perikanan Indonesia, 19(1), 9-16. https://doi.org/10.17844/jphpi.2016.19.1.9

Monalisa, E., Mantiri, F. R, \& Lengkong, H. J. (2019). Kajian variasi sekuens interspesies dan filogeni kelelawar Pteropus sp. menggunakan gen COI. Jurnal MIPA, 8(2), 71-77. https://doi.org/10. 35799/jmuo.8.2.2019.24277

Mujiyanto, \& Syam, A., R. (2015). Karakteristik habitat ikan kerapu di Kepulauan Karimun Jawa, Jawa Tengah. Jurnal BAWAL, 7(3), 147-154. http://dx.doi.org/10.15578/bawal.7.3.2015.147-154

Hariyanto, D. S. T., Mahardika, I. G. N. K., \& Wandia, I. N. (2015). Keragaman spesies ikan tuna di pasar ikan Kedonganan Balidengan: Analisis sekuen kontrol daerah mitokondria DNA. Jurnal Veteriner, 16(3), 416-422. Retrieved from https://ojs.unud.ac.id/index.php/jvet/article/view/16257

Rahim, Z., \& Madduppa, H. (2020). Identifikasi ikan sardin komersial (Dussumieria elopsoides) yang didaratkan di Pasar Muara Angke, Jakarta Menggunakan Pengamatan Morfologi, Morfometrik dan DNA Barcoding. Jurnal Kelautan, 13(2), 93-99. https://doi.org/10.21107/jk.v13i2.6397

Ramadhani, A., Muchlisin, Z.A., Sarong, M.A., \& Batubara, A.S. (2017). Hubungan panjang berat dan faktor kondisi ikan kerapu famili serranidae yang tertangkap di Perairan Pulo Aceh Kabupaten Aceh Besar, Provinsi Aceh. Depik: Jurnal IImu IImu Perairan, Pesisir, dan Perikanan, 6(2), 112- 
121. https://doi.org/10.13170/depik.6.2.7017

Santosa, T.A., Sepriyani, E. M., Razak, A., Chatri, M., \& Violita. (2021). Analisis e-learning dalam pembelajaran evolusi mahasiswa pendidikan biologi selama pandemi COVID-19. Edumaspul: Jurnal Pendidikan, 5(1), 66-70. Retrieved from https://ummaspul.e-journal.id/maspulj/article/ view/1027

Setiawan, H., Fahrudin, A., \& Kamal, M.M. (2019). Analisis hubungan panjang berat pada ikan hermaphrodit: Kerapu sunu (Plectropomus leopardus) dan kerapu macan (Epinephelus fuscoguttatus). Jurnal Biologi Tropis, 19(2), 124-130. https://doi.org/10.29303/jbt.v19i2.1162

Sulistyowati, B. I., Kamal, M., Yonvitner, \& Yulianto, I. (2018). Penilaian kelompok ikan kerapu dengan pendekatan pengelolaan perikanan berbasis ekosistem di Taman Nasional Karimunjawa. Coastal and Ocean Journal, 2(1), 41-56. Retrieved from http://coj.pksplipb.or.id/index.php/coj/article/ view/64

Wirdateti., Indriana, E., \& Handayani. (2016). Analisis sekuen DNA mitokondria cytochrome oxidase I (COI) mtDNA pada kukang Indonesia (Nycticebus spp.) sebagai penanda guna pengembangan identifikasi spesies. Jurnal Biologi Indonesia: Jurnal Penelitian dan Kajian yang Berkaitan dengan Masalah Biologi, 12(1), 119-128. Retrieved from https://e-journal.biologi.lipi.go.id/index.php/jurnal _biologi_indonesia/article/view/2322 